\title{
Penerapan Model Project Based Learning (PBL) untuk Meningkatkan Kreativitas dan Prestasi Belajar Siswa pada Kompetensi Desain Produk dan Pengemasan Karya Rekayasa Elektronika Praktis di Kelas XII IPS,
}

\author{
Sihono Setyo Budi \\ MAN Wates I Kabupaten Kulon Progo \\ sihonosetyobudi@yahoo.co.id
}

\begin{abstract}
This research in aimed to find out if Project Based Learning Model can improve the creativity and learning achievment at class XII IPS $S_{2}$ in MAN 1 Kulon Progo. The subject of this reasearch the students of MAN 1 Kulon Progo at class XII IPS for 30 students. The datum are obtained by using observation sheet and quantitative and qualitative data analysis. It is shown that the are significant improvemens on cycle I, cycle II, and cycle III. The evarega score of learning creativity are 55, on cycle I, 72 on cycle II and 76 on cycle III.Learning achievement also shows a significant improvement between cycle I, cycle II and cycle III. The everage scores of learning achievement are 68,33 on cycle I, 71,25 on cycle II and 74,86 on cycle III. The project achievement done by the students also shows on improvement as much as 85,6\% on cycle I, $88,9 \%$ on cycle II, and $92,2 \%$ on cycle III.
\end{abstract}

Keywords: Project Based Learning Model, Learning Creativity, Learning Achievement.

\begin{abstract}
Abstrak
Penelitian ini betujuan untuk mengetahui mengetahui apakah Model Project Based Learning (PBL) dapat meningkatkan kreativitas dan prestasi belajar di kelas XII IPS, MANI Kulon progo. Subyek penelitian ini adalah siswa MAN Wates I Kulon Progo kelas XII IPS, sebanyak 30 siswa. Data diperoleh dengan menggunakan lembar obsevasi, analisa data menggunakan kuantitatif dan kualitatif. Dari analisa ditemukan bahwa Model Project Based Learning (PBL) dapat meningkatkan kreativitas dan prestasi belajar. Terlihat terdapat peningkatan yang signifikan antara siklus I, siklus II dan siklus III. Jumlah skor rata-rata kreativitas belajar pada siklus I sebesar 55 dan pada siklus II sebesar 72 dan siklus III sebesar 76. Presasi belajar juga mengalami peningkatan yang signifikan antara siklus I, siklus II dan siklus III. Jumlah skor rata-rata prestasi belajar pada siklus I sebesar 68,33, pada siklus II sebesar 71,25 dan siklus III sebesar 74,86. Capaian proyek yang dilaksanakan siswa juga mengalami peningkatan, pada siklus I sebesar 85,6\%, siklus II sebesar 88,9\% dan siklus III sebesar 92,2\%.
\end{abstract}

Kata Kunci: Model Project Based Learning, Kreativitas Belajar, Prestasi Belajar 


\section{PENDAHULUAN}

Kreativitas merupakan istilah yang banyak digunakan baik di lingkungan sekolah maupun di luar sekolah. Pada umumnya orang menghubungkan kreativitas dengan produk- produk kreasi. Dengan kata lain, produk - produk kreasi ini merupakan hal yang penting untuk menilai kreativitas. Dalam dunia pendidikan, tinggi rendahnya kreativitas subjek pendidikan sering dijumpai di lapangan, namun sering dijumpai kreativitas yang rendah. Rendahnya kreativitas sering terjadi pada siswa baik dari tingkat sekolah dasar sampai tingkat sekolah menengah atas bahkan sampai pada tingkat mahasiswa di perguruan tinggi.

Kebanyakan siswa hanya mengejar status, lebih mementingkan nilai yang bagus, bukannya prestasi. Siswa mengejar nilai dengan cara menyontek atau belajar model fotokopy. Keberhasilan pembelajaran khususnya dalam pembelajaran Prakarya dan Kewirausahaan (PKWU) dapat dilihat dari sisi prestasi siswa dan pemahaman serta penguasaan materi yang disampaikan. Semakin tinggi tingkat pemahaman penguasaan materi, makin tinggi pula keberhasilan pembelajaran. Keberhasilan pembelajaran dapat diukur dari kemampuan siswa dalam memahami dan menerapkan berbagai konsep untuk memecahkan masalah dan akhirnya dapat mencapai prestasi yang baik. Setiap pembelajaran tidak lepas dari kesulitan - kesulitan yang dipelajarinya. Setelah mengetahui kesulitan tersebut, guru dapat mengambil manfaat untuk mengadakan perbaikan. Telah banyak cara dilakukan untuk meningkatkan prestasi siswa namun kenyataannya masih rendah bila dibandingkan nilai mata pelajaran lainnya.

Dalam melakukan kegiatan pembelajaran yang terjadi di kelas XII IPS 2 peneliti menemukan permasalahan, yaitu kreativitas belajar dan prestasi belajar siswa pada pelajaran Prakarya dan Kewirausahaan (PKWU) rendah. Rendahnya kreativitas belajar dan prestasi belajar ini, disebabkan karena penggunaan metode pembelajaran yang kurang tepat atau kurang menarik. Hal itu berakibat kurang berkembangnya kreativitas siswa karena tidak adanya kesempatan untuk menyampaikan ideidenya sehingga berpengaruh juga terhadap prestasi belajar siswa.

Rendahnya kreativitas belajar siswa

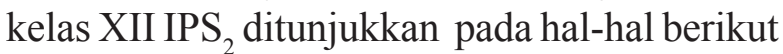
(1) siswa yang berani menjawab pertanyaan dari guru sangat sedikit dari 30 siswa hanya 4 siswa ( $13,33 \%)$ yang menjawab pertanyaan dari guru, perhatian siswa terhadap pelajaran Prakarya dan Kewirausahaan (PKWU) siswa sangatlah kurang, bahkan ada siswa yang tidak memparhatikan pelajaran sama sekali, ada juga yang sibuk mengerjakan pekerjaan rumah mata pelajaran yang lain, (2) keberanian siswa dalam bertanya dan mengerjakan soal di depan tidak tampak, siswa yang tidak ditunjuk oleh guru tidak mau mengeajakan ke depan kelas. Hal ini dapat dilihat dari 30 siswa hanya 3 siswa (10\%) yang maju mengerjakan soal dari guru, (3) siswa tidak memanfaatkan kesempatan tanya jawab materi yang sulit kepada guru, tetapi malah dimanfaatkan untuk bicara sendiri, terlihat tidak adanya siswa yang bertanya kepada guru $(0 \%),(4)$ siswa banyak tidak mempunyai gagasan mengenai masalah, bahkan tidak bisa mengungkapkan gagasan-gagasannya, apalagi untuk berpikir lebih cepat dan melakukan lebih banyak daripada siswa yang lain dalam menghadapi obyek atau masalah tertentu.

Nilai Kriteria Ketuntasan Minimal (KKM) yang dicapai juga belum optimal, dari 30 siswa yang sudah mencapai nilai Kriteria Ketuntasan Minimal (KKM) baru 17 siswa $(56,6 \%)$ sedangkan 13 siswa $(43,3 \%)$ belum. Rendahnya prestasi belajar ini salah satunya karena kreativitas belajar siswa dalam pembelajaran belum optimal. Upaya yang telah dilakukan guru untuk mengatasi permasalahan tersebut, antara lain melakukan diskusi dan tanya jawab. Namun upaya tersebut belum berhasil dikarenakan siswa yang mau bertanya dan berperan aktif dalam pelajaran hanya beberapa siswa saja, sedangkan siswa yang lain hanya sebagai pendengar dan pencatat saja bahkan ada yang tidak memperhatikan sama sekali. Permasalahan di atas menunjukkan bahwa 
pembelajaran perlu diperbaiki. Pembenahan pembelajaran dimulai dari pembenahan proses pembelajaran yang dilakukan guru, antara lain dengan menggunakan suatu model pembelajaran yang mampu meningkatkan kreativitas dan prestasi belajar siswa. Salah satu cara yang ditawarkan dengan menerapkan Project Based Learning atau dikenal dengan Pembelajaran Berbasis Proyek.

Project Based Learning ( $P B L$ ) strategi pembelajaran yang ditujukan untuk menyalurkan minat siswa yang berbeda beda, tugas guru memberi petunjuk sesuatu yang perlu dipelajari. Proyek harus direncanakan dengan baik dan diselesaikan secara kolaboratif, guru mengevaluasi mengevaluasi ketercapaian target yang telah dijadwalkan. ${ }^{1}$

Berdasarkan permasalahan di atas, perlu diadakan suatu pembaharuan untuk merangsang siswa agar bebas dan mau bertanya serta mengutarakan ide-idenya. Hal inilah yang yang kemudian mendorong peneliti untuk mengkaji tentang peningkatan kreativitas belajar dan prestasi belajar dengan Project Based Learning. Pembelajaran berbasis proyek salah satu altenatif dalam pelaksanaan pembelajaran prakarya dan kewirausahaan sebagai bentuk implementasi kurikulum 2013. Peran guru dalam pembelajaran berbasis proyek sebagai fasilitator, pelatih, penasehat dan perantara untuk mendapatkan hasil yang optimal sesuai dengan daya imajinasi, kreasi dan inovasi dari peserta didik. Dalam pelaksanaan pembelajaran berbasis proyek sebaiknya menggunakan team teaching, dan lebih menarik lagi jika suasana ruang belajar tidak monoton, misalnya dengan perubahan lay- out ruang kelas, seperti: traditional class (teori), discussion group (pembuatan konsep dan pembagian tugas kelompok), circle (presentasi), atau dibuat suasana belajar menyenangkan, bahkan saat diskusi dapat dilakukan di taman dan tidak harus dilakukan di dalam ruang kelas. Guru

${ }^{1}$ Wasisto,A.. Proses pembelajarandan penilaiannya, Cet. ke I (Yogyakarta :Graha Cendekia, 2014), hal 107 harus dapat memfasilitasi peserta didik dalam menghadapi masalah, membatasi waktu dalam menyelesaikan proyek, menyediakan peralatan yang sederhana yang terdapat di lingkungan sekitar.

Pembelajaran berbasis proyek dapat membantu peserta didik untuk meningkatkan keterampilan sosial mereka, peserta didik juga menjadi lebih percaya diri dalam berbicara. Antusias peserta didik cenderung untuk dapat dipertahankan secara lebih lama dari apa yang mereka pelajari, sehingga tidak mudah dilupakan. Pembelajaran berbasis proyek merupakan metode pembelajaran yang menggunakan proyek / kegiatan sebagai media. Peserta didik melakukan eksplorasi, penilaian, interpretasi, sintesis, dan informasi untuk menghasilkan berbagai bentuk hasil belajar. ${ }^{2}$

Pembelajaran berbasis proyek merupakan metode belajar yang menggunakan masalah sebagai langkah awal dalam mengumpulkan dan mengintegrasikan pengetahuan baru berdasarkan pengalamannya dalam beraktivitas secara nyata. Langkah-langkah operasionalnya sebagai berikut.

Pertama, menentukan pertanyaan mendasar, tahapan ini guru memberikan pertanyaan yang dapat memberi penugasan peserta didik dalam melakukan suatu aktivitas dengan cara mengambil topik yang sesuai dengan realitas dunia nyata dan dimulai dengan sebuah investigasi mendalam. Guru diharapkan dapat mengangkat topik yang relevan untuk para peserta didik sesuai dengan tuntutan kompetensi. Penyiapan pertanyaan dapat dilakukan diawal semester agar dapat merancang kegiatan selanjutnya.

Kedua, mendesain proyek, perencanaan dilakukan secara kolaboratif antara pendidik dan peserta didik. Dengan demikian, peserta didik diharapkan akan merasa memiliki proyek tersebut. Perencanaan terdiri dari aturan main, pemilihan aktivitas yang dapat

${ }^{2}$ Prasudi, Alternatif Penerapan Pembelajaran Berbasis Proyek dalam mata Pelajaran Prakarya. Makalah. (Yogyakarta: PPPPTK Yogyakarta)

LITERASI, Volume X, No. 12019 
mendukung dalam menjawab pertanyaan esensial, pengintegrasian berbagai subjek yang mungkin, dan alat dan bahan yang dapat diakses untuk membantu penyelesaian proyek.

Ketiga, menyusun jadwal, pendidik dan peserta didik secara kolaboratif menyusun jadwal aktivitas dalam menyelesaikan proyek. Aktivitas pada tahap ini antara lain (1) membuat timeline untuk menyelesaikan proyek, (2) membuat deadline penyelesaian proyek, (3) membawa peserta didik agar merencanakan cara yang baru, (4) membimbing peserta didik ketika mereka membuat cara yang tidak berhubungan dengan proyek, dan (5) meminta peserta didik untuk membuat penjelasan tentang pemilihan suatu cara.

Keempat, memonitor kegiatan dan perkembangan proyek, pendidik mempunyai tanggungjawab untuk memonitor aktivitas peserta didik selama menyelesaikan proyek. Monitoring dilakukan dengan cara memfasilitasi peserta didik pada setiap proses. Dengan kata lain, pemdidik berperan sebagai mentor pada saat peserta didik beraktivitas. Rubrik dapat digunakan untuk mempermudah proses monitoring dan merekam keseluruhan aktivitas peserta didik.

Kelima, menguji hasil penilaian dilakukan untuk membantu pendidik dalam mengukur ketercapaian kompetensi dasar, serta mengevaluasi kemajuan masing- masing peserta didik, memberi umpan balik tentang tingkat pemahaman yang sudah dicapai peserta didik dan membantu pendidik dalam menyusun strategi pembelajaran berikutnya.

Keenam, mengevaluasi kegiatan/ pengalaman, pada akhir pembelajaran guru dan peserta didik melakukan refleksi terhadap aktivitas dan hasil proyek yang sudah dijalankan. Proses refleksi dilakukan baik secara individu maupun kelompok. Pada tahap ini peserta didik diminta untuk mengungkapkan perasaan dan pengalamannya selama menyelesaikan proyek, guru dan peserta didik mengembangkan diskusi dalam rangka memperbaiki kinerja selama proses pembelajaran, sehingga pada akhirnya diperoleh suatu temuan baru (new inquiry) untuk menjawab permasalahan yang diajukan pada tahap awal pembelajaran.
Pemilihan model Project Based Learning memerlukan dukungan persyaratan untuk mereduksi kendala yang sering terjadi, antara lain: peserta didik terbiasa dengan aktivitas pemecahan masalah sehingga proyek tidak memakan waktu terlalu lama, dukungan sarana dan prasarana memadai termasuk peralatan belajar di laboratorium, pengaturan waktu dan jadwal kegiatan yang terkontrol, perlunya kejelasan tugas dan hasil yang diharapkan dari kegiatan proyek.

Manfaat pemilihan model pembelajaran Project Based Learning antara lain (1) meningkatkan motivasi peserta didik untuk belajar, (2) mendorong kemampuan peserta didik melakukan pekerjaan penting, (3) mengembangkan kemampuan peserta didik dalam memecahkan masalah dan berpikir kritis, (4) mengembangkan keterampilan komunikasi, kolaborasi, dan pengelolaan sumber daya, (5) memberikan pengalaman kepada peserta didik pembelajaran dan praktik dalam mengorganisasi proyek dan (6) membuat alokasi waktu serta sumber-sumber lain seperti perlengkapan untuk menyelesaikan tugas melibatkan para peserta didik untuk belajar mengambil informasi dan menunjukkan pengetahuan yang dimiliki kemudian mengimplementasikannya dalam kehidupan sehari-hari sehingga membuat suasana belajar menyenangkan.

Untuk dapat mencapai standar kompetensi yang optimal siswa harus belajar dan salah satu modal penting yang harus dimiliki untuk dapat mencapai keberhasilan dalam bidang akademik adalah kreativitas belajar. Konsep kreativitas belajar pada penelitian ini didasari oleh konsep kreativitas dari Munandar (1992). Kreativitas berhubungan dengan kemampuan berpikir kreatif dan memiliki lima ciri kognitif, yaitu kemampuan berpikir secara lancar (fluency), berpikir luwes (flexibelity), orisinilitas (originality), kemampuan menilai (evaluation) dan kemampuan memerinci/ mendalam (elaboration). ${ }^{3}$ Kemampuan berpikir

${ }^{3}$ Munandar, U. Kreativitas dan keberbakatan strategi mewujudkan potensi kreatif dan bakat, Cet ke 
lancar (fluency), ciri-cirinya dapat dilihat pada sikap siswa dalam bentuk mengajukan banyak pertanyaaan, menjawab dengan sejumlah jawaban jika ada pertanyaan, mempunyai banyak gagasan mengenai suatu masalah, lancar mengungkapkan gagasan-gagasannya, bekerja lebih cepat dan melakukan lebih banyak daripada siswa yang lain, dapat dengan cepat melihat kesalahan atau kekurangan pada suatu obyek atau situasi.

Kemampuan berpikir luwes atau fleksibel (flexibility), ciri-ciri ini dapat dilihat pada sikap siswa dalam memberikan macammacam penafsiran (interpretasi) terhadap suatu gambar, cerita atau masalah, menerapkan suatu konsep dengan cara yang berbeda-beda, memberi pertimbangan terhadap situasi, yang berbeda dari yang diberikan orang lain, dalam membahas atau mendiskusikan suatu situasi selalu mempunyai posisi yang berbeda atau bertentangan dari mayoritas kelompok, jika diberikan suatu masalah biasanya memikirkan macam-macam cara yang berbeda-beda untuk menyelesaikannya, mampu mengubah arah berpikir secara spontan.

Kemampuan berpikir orisinal (originality), ciri-ciri ini dapat dilihat pada sikap siswa dalam memikirkan masalah-masalah atau hal-hal yang tidak pernah terpikirkan oleh orang lain, mempertanyakan cara-cara yang lama dan berusaha memikirkan cara-cara yang baru, memiliki cara berpikir yang lain dari yang lain, setelah membaca atau mendengar gagasangagasan, bekerja untuk menemukan penyelesaian yang baru, memberikan warna-warna yang tegas dan berbeda dengan keadaan aslinya dalam menggambar atau sering mempertanyakan mengapa sesuatu hal harus dilakukan dengan suatu cara dan bukan dengan cara lain.

Kemampuan menilai (evaluation), ciriciri ini dapat dilihat pada sikap siswa dalam memberi pertimbangan atas dasar sudut pandangnya sendiri, menentukan pendapat sendiri mengenai suatu hal, menganalisis masalah atau penyesalan secara kritis dengan

III. (Jakarta: Gramedia Pustaka Utama,2009), hal 10 selalu bertanya dan mempunyai alasan rasional yang dapat dipertanggungjawabkan. Kemampuan memerinci (elaboration), merupakan kemampuan untuk memperkaya atau mengembangkan suatu ide, gagasan atau produk dan kemampuan untuk memerinci suatu obyek, gagasan, dan situasi sehingga tidak hanya menjadi lebih baik tetapi menjadi lebih menarik. Prestasi belajar merupakan hal yang tidak dapat dipisahkan dari kegiatan belajar, karena kegiatan belajar merupakan proses, sedangkan prestasi merupakan hasil dari proses belajar. Prestasi belajar merupakan pencerminan hasil belajar yang dicapai setelah mengikuti proses belajar mengajar. Dengan memperhatikan prestasi belajar dapat diketahui kemampuan dan kualitas siswa. ${ }^{4}$

Prestasi belajar siswa dapat diketahui melalui pelaksanaan evaluasi atau assessment, karena dengan cara itulah dapat diketahui tinggi rendahnya prestasi belajar siswa atau baik buruk prestasi belajarnya. Di samping itu evaluasi berguna pula untuk mengukur tingkat kemajuan yang dicapai oleh siswa dalam satu kurun waktu proses belajar tertentu, juga untuk mengukur posisi atau keberadaan siswa dalam kelompok kelas serta mengetahui tingkat usaha belajar siswa. Data yang diperoleh pendidik selama pembelajaran berlangsung dapat dikumpulkan melalui prosedur dan alat penilaian sesuai dengan kompetensi atau hasil belajar yang akan dinilai. Dari proses ini diperoleh potret kemampuan peserta didik dalam mencapai sejumlah kompetensi dasar yang tercantum dalam kurikulum. Indikator keberhasilan belajar adalah patokan yang ditentukan oleh kriteria pencapaian kompetensi dasar dan standar kompetensi yang telah ditetapkan yang mencirikan penguasaan konsep atau keterampilan yang dapat diamati dan diukur. Mengacu pada kriteria minimal yang ditetapkan untuk mata pelajaran Prakarya dan Kewirausahaan (PKWU) di MAN I Kulon progo

${ }^{4}$ Budi,S \& Widyana, Korelasi antara Kreativitas, Motivasi, dan Kemandirian belajar siswa dengan prestasi belajar Jurnal Insight Vol. 10, No 1, ( Yogyakarta : Pasca Sarjana UMBY), 2012 
sebesar 72. Berdasarkan landasan teori yang telah diuraikan di atas maka peneliti mengemukakan hipotesis: Dengan menggunakan metode Project Base Learning Kreativitas dan prestasi belajar siswa kelas XII IPS 2 meningkat.

\section{METODOLOGI PENELITIAN}

Penelitian ini adalah Penelitian Tindakan Kelas (PTK) yang dilakukan secara kolaboratif antara guru mata pelajaran PKWU dan peneliti yang dilaksanakan di Madrasah Aliyah Negeri I Kulon Progo (MAN I Kulonprogo). Peran guru mata pelajaran sebagai kolaborator, sedangkan peneliti sebagai pelaksana pembelajaran. Keduanya terlibat sejak perencanaan, pelaksanaaan, pengamatan hingga refleksi terhadap pembelajaran. ${ }^{5}$

Subjek penelitian ini adalah siswa kelas XII IPS2 MAN I Kulon Progo tahun pelajaran 2017 / 2018 sejumlah 30 siswa yang dipandang peneliti mempunyai kreativitas dan prestasi belajar yang rendah. Penelitian dilaksanakan di MAN I Kulon Progo Jalan Mandung Pengasih Kulon Progo. Di mulai tanggal 1 Agustus 2017 sampai 30 Oktober 2017.

Penelitian direncanakan 3 siklus sampai indikator keberhasilan tercapai. Setiap siklus terdiri dari 3 pertemuan meliputi (1) perencanaan, (2) pelaksanaan, (3) observasi, (4) pengukuran kreativitas, (5) pengukuran prestasi, dan (6) refleksi. Analisis penelitian deskriptif kualitatif, yaitu penelitian ini lebih bersifat mendeskripsikan data berdasarkan fakta dan keadaan yang terjadi di sekolah tersebut.

\section{HASIL DAN PEMBAHASAN Siklus I}

Pembelajaran pada siklus I dilaksanakan selama tiga kali pertemuan dan diakhiri dengan pengkuran kreativitas, capaian proyek, dan pengukuran prestasi belajar. Tindakan yang dilakukan pada siklus I sebagai berikut.

${ }^{5}$ Anonim, Kurikulum Man Wates I Kulon Progo Tahun Pelajaran 2017/2018 (Yogyakarta: MAN I Kulon progo) 2018
Perencanaan, tahap ini peneliti menyusun Rencana Pelaksanaan Pembelajaran (RPP), Lembar Kerja Siswa (LKS) dan beberapa instrumen observasi yaitu: instrumen observasi capaian proyek, instrumen observasi kreativitas belajar siswa, instrumen penilaian proyek yang mencerminkan prestasi belajar dan instrumen observasi pembelajaran yang digunakan sebagai catatan selama proses belajar mengajar berlangsung.

Pelaksanaan tindakan, pembelajaran pada siklus pertama dilaksanakan selama tiga kali pertemuan yaitu pada tanggal 10,24, dan 31 Agustus 2017 dengan durasi 90 menit (2x45 menit), dengan materi pembuatan Printed Circit Board (PCB) yang meliputi desain rangkaian, desain alur, pelarutan dan pelobangan. Guru memulai pembelajaran dengan mengingatkan kembali materi sebelumnya, selanjutnya memberikan motivasi dan menjelaskan cara mendesain rangkaian, mendesain alur, melarutkan, dan mengebor. Adapun tindakan yang dilakukan oleh guru adalah (1) guru memberikan permasalahan yang esensial berupa pertanyaan yang dapat memberikan penugasan terhadap untuk melakukan aktifitas. Topik yang diambil yang ambil menegenai masalah desain produk dan pengemasan karya rekayasa elektronika praktis (inverter). Kemudian membentuk kelompok menjadi 6 kelompok dengan anggota 5 orang, diberikan Lembar Kerja Siswa (LKS) untuk dikerjakan. Guru mengawasi jalannya kerja kelompok dan observer mengamati sekaligus mencatat aktivitas siswa dan pembelajaran yang terjadi. Pada awal kelihatan masih gaduh dan tidak terkoordinasi dengan baik karena harus menjawab pertanyaan yang esensial permasalahan yang terjadi dimasyarakat yang berkaitan dengan elektronika praktis, (2) guru mengajak siswa untuk merencanakan proyek dengan menuliskan keadaan yang terjadi di sekitar tempat tinggal masing-masing disaat lampu penerangan mati. Ada yang mengatakan keadaan gelap, ada yang menyalakan lilin, ada yang menggunakan lampu emergensi, lampu senter dan lain-lain. Kemudian siswa diajak oleh 
guru memikirkan peralatan apa yang sekiranya dapat menghidupkan lampu disaat terjadi pemadaman, maka siswa menjawab dibuatlah alat yang dapat menghidupkan lampu. Maka diputuskan bahwa proyek pada pembelajaran ini membuat inverter sebagai sumber listrik disaat terjadi pemadaman listrik. Selanjutnya siswa diajak mendesain rangkaian inverter yang dapat mengubah arus searah (DC) menjadi bolak-balik (AC). Awalnya siswa masih gaduh, ada yang membuka buku diktat, ada yang tanya temannya, ada yang bertanya pada guru. ada masih diam memikirkan apa yang harus di desain. Dibawah bimbingan guru siswa diajak berpikir tentang rangkaian yang dapat menghasilkan ftreuensi. Akhirnya sebagian siswa sudah ada yang bisa membuat desain rangkaian, ada yang mendesain dengan IC 555, ada yang mendesain multivibrator, ada yang mendesain flip-flop. Dengan berbagai model desain akirnya disepakai dengan menggunakan rangkaian flip flop dan di driver dengan MOSFET, (3) guru mengajak siswa mementukan berapa lama waktu pengerjaan proyek yang meliputi time line untuk menyelesaiakn proyek, dan dead line penyelesaian proyek dan cara yang digunakan, disepakai proyek ini akan selesai selama 3 minggu ( $3 x$ pertemuan). Yang meliputi desain rangkaian, desain alur, pelarutan dan pelobangan. Pada pertemuan kedua dilanjutkan membuat desain alur pada Printed Circit Board (PCB), dan pada pertemuan selanjutnya desain alur yang sudah benar dilarutkan pada larutan ferid cholride untuk menghilangkan bagian yang tidak terpakai. Dan dilanjutkan dibor menggunakan ukuran bor $1 \mathrm{~mm}$. Semua kegiatan dilakukan siswa dengan bimbingan guru dengan menggunakan Lembar Kerja Siswa (LKS), (4) selanjutnya guru mengamati aktivitas pengerjaan proyek dan memonitor capaian kerja proyek setiap minggunya dan mencatat kegiatan siswa selama pembelajaran berlangsung sebanyak 3 kali pertemuan, (5) guru juga melakukan pengukuran prestasi dengan melihat hasil desain Printed Circit Board (PCB), pada tahap ini dilakukan pengukuran ketercapaian standar guna mengevaluasi kemajuan peserta didik yang akan digunakan untuk menyususn strategi pada pembelajaran berikutnya dan di evaluasi kekurangan dan kelebihannya sambil dilakukan pengukuran kreativitas belajar siswa, (6) selanjutnya siswa diminta untuk refleksi secara kelompok untuk mengemukakan perasaaan serta menuliskan dan pengalamannya selama mengerjakan proyek pembuatan Printed Circit Board (PCB).

Guru mengajak siswa untuk mengembangkan diskusi dalam rangka memperbaiki kinerja selama proses pembuatan Printed Circit Board (PCB), sehingga di temukan cara pembuatan yang baru. Berikut adalah pengalaman baru yang dihasilkan dari diskusi berupa langkah pembuatan Printed Circit Board (PCB) yaitu (1) mendesain rangkaian dan alur, (2) melarutkan dengan ferit chloride, (3) mengebor, (4) melapisi permukaan, dan (5) merangkai komponen.

Tahap pengamatan, dilaksanakan dengan bantuan teman sejawat. Adapun hal yang diamati selama proses pembelajaran berlangsung terekam dalam lembar obervasi yang meliputi keterlaksanaan proses pembelajaran, capaian kemajuan proyek, kretifitas siswa dan hasil proyek (prestasi siswa).

Tahap refleksi, hasil diskusi yang dilakukan oleh peneliti dan observer terhadap pelaksanaan pembelajaran siklus I beberapa hambatan dan kekurangan antara lain (1) masih ada siswa yang belum mampu menjawab permasalahan yang terjadi di masyarakat berkaitan dengan topik pembelajaran desain produk dan pengemasan karya rekayasa elektronika praktis, (2) masih ada siswa yang belum mampu dalam mengerjakan tugas yang diberikan guru terutama dalam mendesain rangkaian masih perlu bimbingan yang intensif, (3) masih ada siswa yang belum mampu mendesain alur sehingga guru perlu membantu terutama dalam menghitamkan dengan spidol permanen, (4) sebagian siswa belum mampu merencanakan waktu yang tepat sehingga pelaksanaan proyek tidak sesuai rencana telah ditentukan, (5) sebagian siswa kurang aktif masih menunggu bantuan guru dan hasil kerja 
kawannya, peran guru sebagai mentor sangat dominan, (6) hasil masih ada yang belum sesuai dengan stantar ketercapaian, alur dan desain masih kurang baik walaupun dapat berfungsi, (7) banyak yang tidak mau bertanya pada guru, padahal kurang mampu dalam mengerjkan proyek, (8) siswa masih takut mendiskusikan pengalaman belajarnya selama mengerjakan proyek pada teman dan guru.

Guru bersama observer berdiskusi untuk memberikan solusi terhadap permasalahan yang terjadi pada siklus I untuk dilaksanakan pada siklus ke II dengan alternatif sebagai berikut (1) mengubah kelompok dalam mengerjakan proyek (kocok ulang), (2) siswa diajak menjawab permasalahan yang terjadi di masyarakat berkaitan dengan topik pembelajaran desain produk dan pengemasan karya rekayasa elektronika praktis, (3) siswa yang belum mampu dalam mengerjakan tugas yang diberikan motivasi dan diberikan beberapa contoh desain, (4) siswa yang belum mampu merencanakan waktu dengan tepat untuk mengerjakan proyek, diajak mengestimasikan waktu sehingga pelaksanaan proyek sesuai waktu yang ditentukan, (5) siswa yang kurang aktif difasilitasi dalam setiap proses, sehingga peran guru sebagai mentorbagi aktivitas siswa. (6 ) hasil proyek harus sesuai dengan stantar ketercapaian, dan dengan memperhatikian langkah kerja di lembar kerja, (8) siswa dirangsang untuk aktif dan mau bertanya pada guru, dalam mengerjakan proyek, (9) siswa dirangsang dengan pemberian nilai plus bagi yang mau mendiskusikan pengalaman belajarnya selama mengerjakan proyek pada teman dan guru di depan kelas.

\section{Siklus II}

Rancangan pada siklus II hampir sama dengan siklus I akan tetapi dilakukan perbaikan - perbaikan rencana tindakan. Pada siklus II ini merupakan kelanjutan dari siklus I sampai proyek dapat berfungsi dengan baik. Adapun rencana tindakan yang akan dilaksanakan sebagai berikut.

Perencanaan, tahap ini peneliti menyusun Lembar Kerja Siswa (LKS) serta instrumen observasi, antara lain : instrumen observasi capaian proyek, instrumen observasi Kreativitas belajar siswa, instrumen penilaian proyek yang mencerminkan prestasi belajar dan instrumen observasi pembelajaran yang digunakan sebagai catatan selama proses belajar mengajar berlangsung.

Pelaksanaan tindakan, pembelajaran pada siklus kedua pada tanggal 7,14 dan 28 September 2017 dengan durasi 90 menit (2x45 menit), dengan materi merangkai komponen dan uji coba rangkaian inverter. Pada pertemuan pertama siswa sudah terbiasa dengan situasi kelas yang diamati. Guru memulai pembelajaran dengan mengingatkan kembali materi sebelumnya, selanjutnya memberikan motivasi dan membentuk kelompok menjadi 6 kelompok dengan anggota 5 orang, diberikan Lembar Kerja Siswa (LKS) untuk dikerjakan. Adapun tindakan yang dilakukan adalah (1) guru mengawali pelajaran dengan sebuah pertanyaan yang mendasar bagaimana cara mengatasi keruwetan sambungan antar komponen? Bagaimana cara menghubungkan antar komponen? Pertanyaan ini dihubungkan dengan realitas yang nyata. Sebagian siswa menjawab dibuat blok-blok, dibuat rangkaian pengganti kabel, dibuat papan penghubung, dibuat papan rangkaian tercetak, ada berbagai berbagai jawaban, kemudian guru memberikan penguatan materi tentang bagaimanan memasang komponen, membaca kode angka, kode warna dan cara menyolder yang baik, (2) siswa juga diarahkan bekerja secara kolaboratif merencanakan proyek pemasangan komponen, dan uji coba rangkaian serta peralatan apa yang harus digunakan untuk mengerjakan proyek tersebut, (3) siswa diarahkan untuk mementukan berapa lama waktu pengerjaan proyek merangkaian komponen dan uji coba tersebut, waktu yang disepakai proyek ini akan selesai selama 3 minggu ( $3 x$ pertemuan). Yang meliputi merangkai komponen, pengawatan dan uji coba, (4) guru mengamati capaian kerja proyek setiap minggunya dan mencatat kegiatan siswa selama pembelajaran berlangsung. Guru memfasilitasi siswa dalam setiap proses 
megerjakan proyek, (5) guru juga melakukan pengukuran prestasi dengan melihat hasil siswa yang meliputi perencanaa, persiapan, teknik merangkai, keselamatan dalam merangkai dan menguji komponen, bentuk fisik rangkaian dan inovasi yang dilakukan siswa. Selanjutnya pada pertemuan yang terakir dilakukan uji coba rangkaian ada yang berfungsi dengan baik, ada juga yang belum maka dibawah bimbingan guru semuanya dapat berfungsi, (6) guru mengevaluasi kemajuan peserta didik yang akan digunakan untuk menyusun strategi pada pembelajaran berikutnya, kekurangan dan kelebihannya unuk diperbaiki pada siklus berikutnya.

Guru mengajak siswa untuk mengembangkan diskusi dalam rangka memperbaiki kinerja selama proses merangkai dan menguji komponen, sehingga di temukan cara baru yang lebih baik. Berikut adalah pengalaman baru yang dihasilkan dari diskusi berupa langkah merangkai komponen yaitu (1) menyiap solder dan timah, diawali dari komponen pasif(resistor, capasitor), kemudian komponen aktif tansistor ( FET). (2) menyolder kaki komponen pada Printed Circit Board $(P C B)$ menggunakan timah hasil solder yang baik permukaan timah kelihatan mengkilat, (3) potong kaki komponen, (4) melakukan pengawatan, (5) melakukan uji coba rangkaian.

Tahap pengamatan, dilaksanakan dengan bantuan teman sejawat. Adapun hal yang diamati selama proses pembelajaran berlangsung terekam dalam lembar obervasi yang meliputi keterlaksanaan proses pembelajaran, capaian kemajuan proyek, kretifitas siswa dan hasil proyek ( prestasi siswa).

Tahap refleksi, dilakukan oleh peneliti dan observer terhadap pelaksanaan pembelajaran siklus II beberapa hambatan dan kekurangan antara lain (1) Siswa mulai mampu menjawab permasalahan yang terjadi di masyarakat berkaitan dengan topik merangkai dan menguji komponen rekayasa elektronika praktis ( inverter) namum masih perlu bimbingan, (2) dalam mengerjakan tugas yang diberikan guru terutama pemasangan komponen dan menguji rangkaian perlu bimbingan dari guru, (3) siswa sudah mulai menggunakan waktu sesuai dengan yang ditentukan, (4) peran guru sudah mulai berkurang siswa mulai aktif mengerjakan proyek, (5) hasil pemasangan komponen masih kurang baik walaupun dapat berfungsi, (6) siswa mulai aktif bertanya pada guru untuk menyelesaikan proyek, (7) siswa sudah mulai berani mendiskusikan pengalaman belajarnya selama mengerjakan proyek pada teman dan guru.

Guru bersama observer berdiskusi untuk memberikan solusi terhadap permasalahan yang terjadi pada siklus II untuk dilksanakan pada siklus ke III dengan alternatif sebagai berikut (1) siswa diajak mampu menjawab permasalahan yang terjadi di masyarakat berkaitan dengan topik pembelajaran desain produk dan pengemasan karya rekayasa elektronika praktis, (2) diberikan motivasi dan diberikan beberapa contoh desain box pengemasan,. (3) siswa harus mampu merencanakan waktu dengan tepat, (4) peran guru sebagai mentor bagi aktivitas siswa, (5) hasil proyek harus sesuai dengan stantar ketercapaian, dan berfungsi dengan baik, (6) siswa dirangsang untuk aktif dan mau bertanya pada guru, dalam mengerjakan proyek ( berpedoman pada Lembar Kerja Siswa (LKS), (7) siswa harus mau mendiskusikan pengalaman belajarnya selama mengerjakan proyek pada teman dan guru di depan kelas.

\section{Siklus III}

Rancangan pada siklus III hampir sama dengan siklus II akan tetapi dilakukan perbaikan - perbaikan rencana tindakan. Pada siklus III ini merupakan kelanjutan dari siklus II sampai proyek dapat berfungsi dengan baik. Adapun rencana tindakan yang akan dilaksanakan sebagai berikut.

Perencanaan, tahap ini peneliti menyusun Lembar Kerja Siswa (LKS) serta instrumen observasi, antara lain : instrumen observasi capaian proyek, instrumen observasi kreativitas belajar siswa, instrumen penilaian proyek yang mencerminkan prestasi belajar dan instrumen observasi pembelajaran yang digunakan 
sebagai catatan selama proses belajar mengajar berlangsung.

Pelaksanaan tindakan dan observasi, pada siklus ketiga dilaksanakan tanggal 5, 12 dan 19 Oktober 2017 dengan durasi 90 menit $(2 \times 45$ menit), dengan materi desain dan pengamasan. Pada pertemuan pertama siswa sudah terbiasa dengan situasi kelas yang diamati. Guru memulai pembelajaran dengan mengingatkan kembali materi sebelumnya, selanjutnya memberikan motivasi dan membentuk kelompok menjadi 6 kelompok dengan anggota 5 orang, diberikan Lembar Kerja Siswa (LKS).

Adapun tindakan yang dilakukan adalah (1) Guru mengawali pelajaran dengan sebuah pertanyaan yang mendasar. Agar sebuah produk mempunyai daya tarik dan laku di pasaran hal apakah yang perlu kalian lakukan? Pertanyaan ini dihubungkan dengan realitas yang nyata. Berbagai macam jawaban siswa antara lain (a) kelompok 1 menjawab dibuat kemasan pada produk dan beberapa informasi jenis produk, fungsi dan cara pemakaian, (b) kelompok 2 menjawab dibuat kemasan yang kuat dan bagus, (c) kelompok 3 menjawab dijual harga yang murah, (d) kelompok 4 menjawab dijual harga dengan yang murah, (e) kelompok 5 menjawab kemasan menampilkan citra produk dan segmen pasar, (f) kelompok 6 menjawab bentuk kemasan bagus dan mudah digunakan.

Dari beberapa jawaban guru memberikan penguatan materi tentang bagaimanan sebuah produk mempunyai kemasan yang menarik kuat dan memberikan informasi yang jelas tentang produk tersebut.

(2) Siswa juga diarahkan bekerja secara kolaboratif merencanakan bok / kemasan produk, seta peralatan dan bahan yang harus digunakan untuk mengerjakan proyek tersebut. (3) Siswa diarahkan untuk mementukan berapa lama waktu pengerjaan proyek pembuatan kemasan, waktu yang disepakai proyek ini akan selesai selama 3 minggu ( $3 x$ pertemuan). Yang meliputi desain kemasan pemasangan dan uji coba produk.

(4) Guru mengamati capaian kerja proyek setiap minggunya dan mencatat kegiatan siswa selama pembelajaran berlangsung. Guru memfasilitasi siswa dalam setiap proses megerjakan proyek. (5) Guru juga melakukan pengukuran prestasi dengan melihat hasil siswa yang meliputi perencanaa, persiapan, teknik merangkai komponen, keselamatan dalam merangkai dan menguji komponen, bentuk fisik kemasan dan inovasi yang dilakukan siswa. Selanjutnya pada pertemuan yang terakir dilakukan uji coba pengemasan produk sampai dapat berfungsi dengan baik. Siswa yang belum mampu mendesain kemasan dibimbingan guru sehingga dapat mendesain dengan baik.

(6) Guru mengevaluasi kemajuan peserta didik yang akan digunakan untuk menyusun strategi pada pembelajaran berikutnya, kekurangan dan kelebihannya untuk diperbaiki. Guru mengajak siswa untuk mengembangkan diskusi dalam ragka memperbaiki kinerja selama proses pembuatan kemasan produk, sehingga di temukan desain baru yang baik. Berikut adalah pengalaman baru yang dihasilkan dari diskusi berupa langkah pengemasan: mendesain kemasan inverter, membuat lobang untuk komponen ( lampu indikator, fuse, meter, output dan input), memasang komponen berupa lampu indikator, fuse, meter, output dan input, menghubungkan komponen dengan rangakaian inverter, melakukan uji coba rangkaian inverter, menutup kemasan dengan baut, dan memasang label.

Tahap pengamatan, dilaksanakan dengan bantuan teman sejawat. Adapun hal yang diamati selama proses pembelajaran berlangsung terekam dalam lembar obervasi yang meliputi keterlaksanaan proses pembelajaran, capaian kemajuan proyek, kretifitas siswa dan hasil proyek ( prestasi siswa).

Tahap refleksi dilakukan oleh peneliti dan observer terhadap pelaksanaan pembelajaran siklus III beberapa kelebihan dan kekurangan antara lain (1) siswa mulai mampu memecahkan permasalahan yang terjadi di masyarakat berkaitan dengan topik mendesain kemasan produk rekayasa inverter, (2) dalam mengerjakan desain kemasan Kreativitas siswa sudah terlihat di buktikan dengan banyaknya 
aneka desain kemasan, (3) penggunaa waktu sudah sesuai dengan yang ditentukan, (4) guru berperan sebagai mentor, siswa mulai aktif mengerjakan proyek pembuatan desain kemasan, (5) hasil desain kemasan baik bentuk maupun tampilan sudah cukup baik, (6) siswa mulai aktif bertanya pada guru untuk menyelesaikan proyek, (7) siswa sudah mulai berani mendiskusikan pengalaman belajarnya selama mengerjakan proyek pada teman dan guru.

\section{PEMBAHASAN}

Dari diskripsi hasil penelitian yang telah diuraikan di atas diketahui bahwa pembelajaran Prakarya dan Kewirausahaan (PKWU) dengan menggunakan model Project Base Learning $(P B L)$ terbukti dapat meningkatkan kreativitas belajar siswa di kelas XII IPS 2, seperti pada grafik berikut.

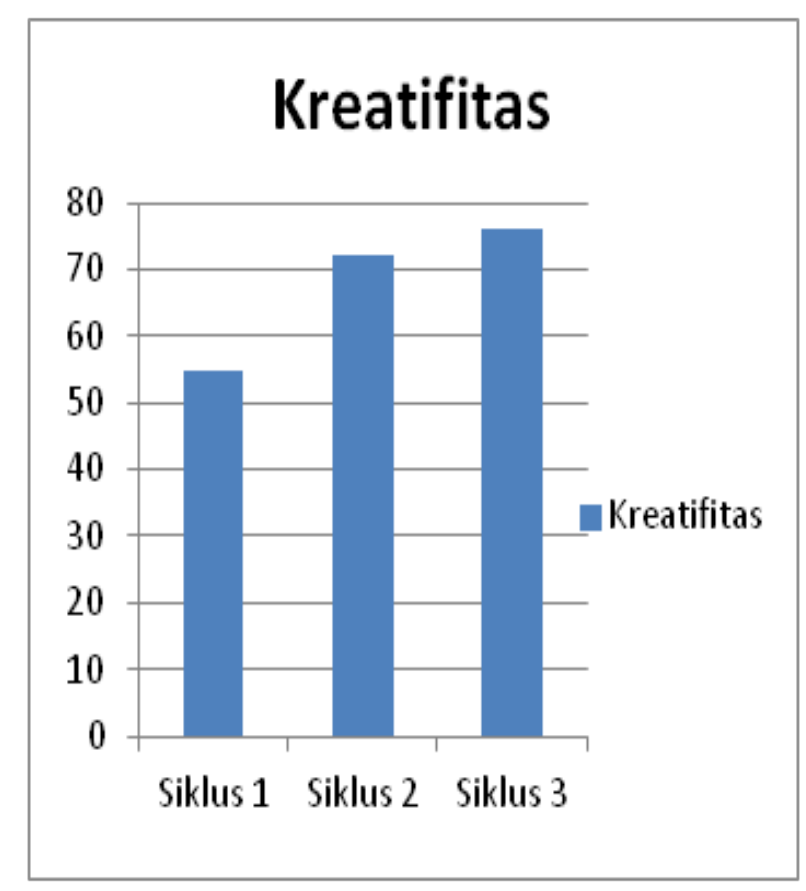

Gambar. grafik kreativitas belajar siswa

Terlihat bahwa kreativitas siswa mengalami kenaikan dari siklus I sebesar 55 dengan kategori cukup, kemudian pada siklus II sebesar 72 dengan kategori baik dan di akhir siklus III menjadi 76 dengan kategori baik. Skor rata-rata tiap aspek kreativitas belajar siswa dalam dalam mengerjakan proyek juga mengalami peningkatan.

Pada siklus I aspek kemampuan berpikir secara lancar (fluency) sebesar 5,85, siklus II sebesar 6,81, dan siklus III sebesar 6,81 ini mengandung arti bahwa terjadi peningkatan sikap siswa dalam hal mengajukan pertanyaaan, menjawab sejumlah pertanyaan, banyak gagasan mengenai suatu masalah, lancar mengungkapkan gagasan-gagasannya, bekerja lebih cepat dan melakukan lebih banyak daripada siswa yang lain, dapat dengan cepat melihat kesalahan atau kekurangan pada masalah yang dihadapi.

Pada aspek berpikir luwes (flexibelity) pada siklus I sebesar 2,81, siklus II sebesar 3,23, dan siklus III sebesar 3,62 mengandung arti terjadi peningkatan sikap siswa dalam hal manafsiran (interpretasi) gambar, masalah, menerapkan konsep dengan cara yang berbeda, memberi pertimbangan yang berbeda dari yang diberikan orang lain, dan dapat mendiskusikan suatu situasi yang berbeda atau bertentangan dari mayoritas kelompok. mampu mengubah arah berpikir secara spontan.

Pada aspek berpikir orisinilitas (originality) pada siklus I sebesar 2,31, siklus II sebesar 2,27, dan siklus III sebesar 2,42 mengandung arti terjadi peningkatan sikap siswa dalam hal memikirkan masalah-masalah atau hal-hal yang tidak pernah terpikirkan oleh orang lain, mempertanyakan cara-cara yang lama dan berusaha memikirkan cara-cara yang baru, memiliki cara berpikir yang lain dari yang lain, memberikan warna berbeda dengan keadaan aslinya.

Pada aspek evaluation pada siklus I sebesar 1,31, siklus II sebesar 1,38, dan siklus III sebesar 1,65 mengandung arti terjadi peningkatan sikap siswa dalam hal memberi pertimbangan dengan pandangnya sendiri, menentukan pendapat sendiri, menganalisa masalah dan penyelesaiannya mempunyai alasan rasional yang dapat dipertanggungjawabkan.

Pada aspek elaboration pada siklus I sebesar 0,46, siklus II sebesar 0,62, dan siklus III sebesar 0,73 mengandung arti 
terjadi peningkatan sikap siswa dalam hal mengembangkan suatu ide, gagasan atau produk dan kemampuan sehingga menjadi lebih baik dan lebih menarik. Dengan kata lain bahwa Kreativitas siswa mengalami peningkatan.

Dengan menggunakan metode Project Base Learning (PBL) terbukti dapat meningkatkan prestasi belajar siswa di kelas XII IPS ${ }_{2}$, seperti pada grafik berikut.

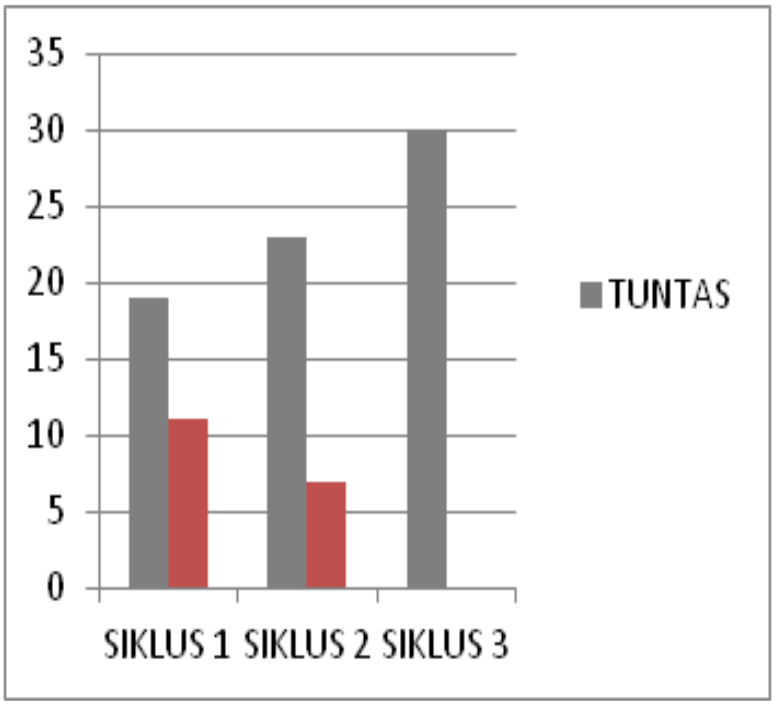

Gambar 2. grafik ketuntasan belajar siswa

Terjadi peningkatan prestasi belajar, pada siklus I siswa yang tuntas belajar sebanyak 19, siklus II sebesar 23 dan pada siklus II sebanyak 30 siswa. Rerata skor prestasi siswa juga mengalami peningkatan yaitu siklus I sebesar 68,33 , siklus II sebesar 71,25 dan siklus III 74,86.

Dari grafik dapat disimpulkan bahwa dengan mengunakan metode Project Base Learning ( $P B L$ ) proses mengerjakan proyek desain produk dan pengemasan karya rekayasa elektronika praktis, mengalami peningkatan. Artinya pada siklus I siswa mampu mengerjakan proses desain rangkaian rangkaian sampai tercetak Printed Circuit Board (PCB). Dilanjutkan pada siklus II siswa mampu mengerjakan proses perakitan komponen, pengawatan dan pengujian. Pada siklus III ini siswa mampu mengerjakan pengemasan produk sampai produk dapat di pakai dan dipasarkan.

Dengan menggunakan metode Project Base Learning (PBL) terbukti dapat

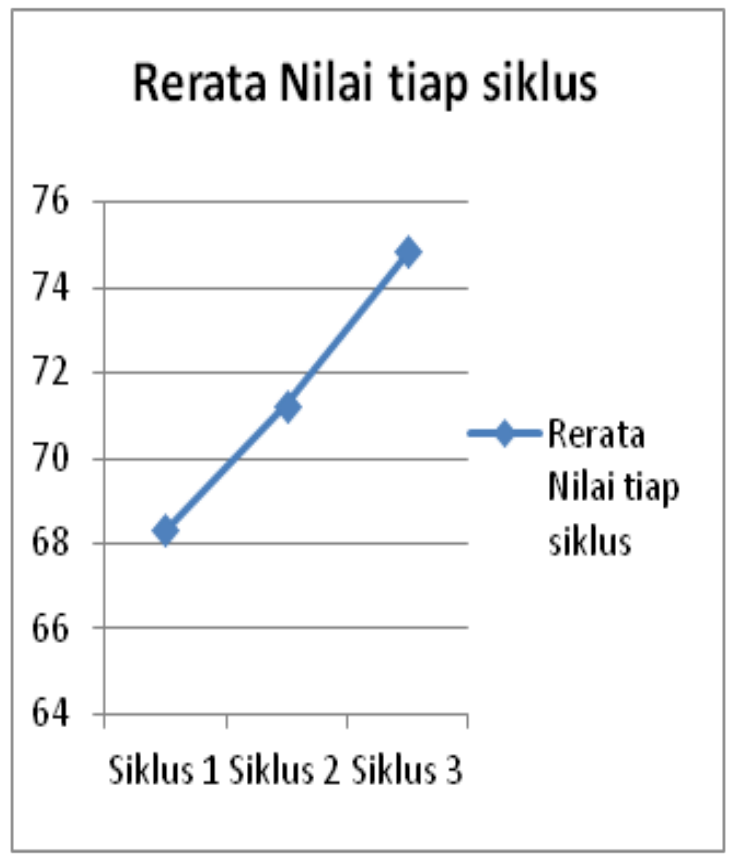

Gambar 3. Grafik Rerata Nilai

meningkatkan capaian dalam mengerjakan proyek, seperti terlihat pada grafik berikut.

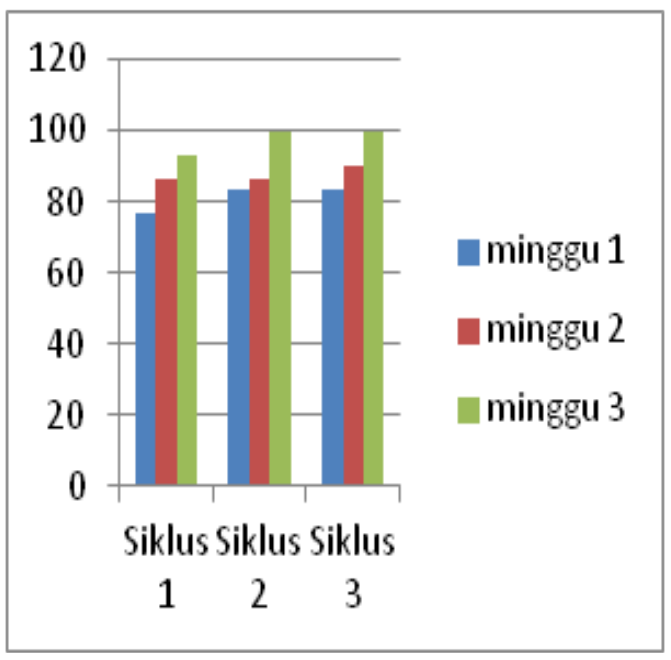

Gambar 4. Grafik capaian proyek

Terlihat dari skor rata-rata capaian proyek yang diperoleh siswa pada siklus I, siklus II, dan siklus III. Capaian proyek pada siklus I sebesar $85,6 \%$, pada siklus II sebesar 88,9\%, dan pada siklus III sebesar 92,2\%. Dapat diartikan bahwa pada siklus I dari 30 siswa 26 siswa yang mengerjakan sesuai rencana dan 4 siswa belum, pada siklus II dari 30 siswa 27 siswa yang mengerjakan sesuai rencana dan 3 siswa belum, pada siklus III dari 30 siswa 28 
siswa yang mengerjakan sesuai rencana waktu yang disepakati dan 2 siswa belum.

Pembelajaran PKWU dengan menggunakan model model Project Base Learning $(P B L)$ telah dilaksanakan guru pada siklus I sebesar $76,7 \%$, pada siklus II sebesar $86 \%$ dan pada siklus III sebesar $96 \%$. Mengandung artinya bahwa 96\% langkahlangkah pembelajaran dengan metode Project Base Learning (PBL) telah dilaksanakan guru pada akhir siklus III.

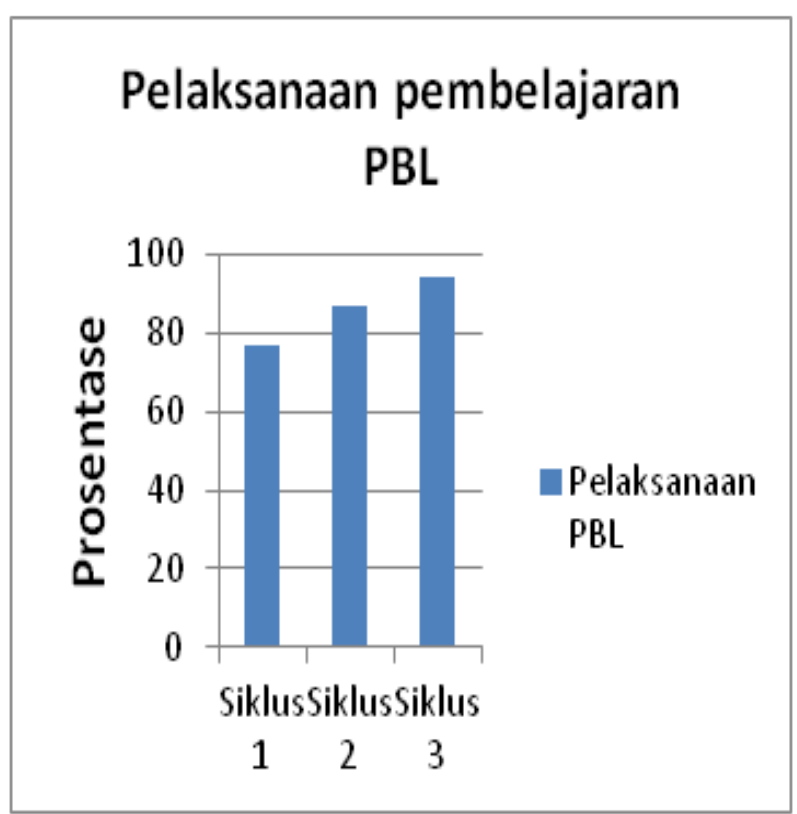

Gambar 5. Grafik Pelaksanaan PBL

Dari pembahasan diatas dapat disimpulkan bahwa dengan menggunakan metode Project Base Learning (PBL) dapat meningkatkankan Kreativitas belajar dan prestasi belajar siswa kelas XII IPS.

\section{KESIMPULAN}

Berdasarkan hasil penelitian dan pembahasan dapat disimpulkan dengan menggunakan Project Base Learning (PBL) dapat meningkatkan kreativitas dan prestasi belajar siswa belajar siswa pada mata pelajaran PKWU di kelas XII IPS 2 MAN 1 Kulon Progo.

\section{DAFTAR PUSTAKA}

Anonim, 2014. Pembelajaran Prakarya dan Kewirausahaan : Direktorat Pembinaan Sma, Jakarta .

Anonim, 2018. Kurikulum Man Wates I Kulon Progo Tahun Pelajaran 2017/2018: MAN I Kulon progo,Yogyakarta

Budi,S 2012. Korelasi antara Kreativitas, Motivasi, dan Kemandirian belajar siswa dengan prestasi belajar, Jurnal Insight. Vol 10 No 1 UMBY, Yogyakarta.

Munandar, U. 1987. Mengembangkan bakat dan kreativitas anak sekolah petunjuk bagi para guru dan orang tua. Gramedia Pustaka Utama, Jakarta

Prasudi, Fajar 2013. Alternatif Penerapan Pembelajaran Berbasis Proyek Dalam Mata Pelajaran Prakarya, http://www. edutopia.org/modules/PBL/whatpbl.php. Diakses tanggal 13 Juli 2017.

Wasisto, A 2014. Proses Pembelajaran dan penilaiannya. Graha Cendekia, Yogyakarta

Hasanah, M. 2007. Tingkat kreativitas dengan prestasi belajar pada siswa sekolah dasar Thesis. Malang: UMM.

Munandar, U. 1992. Kreativitas dan keberbakatan strategi mewujudkan potensi kreatif dan bakat. Jakarta: Gramedia Pustaka Utama.

Munandar, U . 1988. Kreativitas sepanjang masa. Jakarta: Pustaka Sinar Harapan.

Munandar, U. (2009). Pengembangan kreativitas anak berbakat. Jakarta: Rineka Cipta. 